\title{
Winter Habitat Use by Wolves, Canis lupus, in Relation to Forest Harvesting in West-central Alberta
}

\author{
Gerald W. KuZyK ${ }^{1,3}$, JefF Kneteman ${ }^{2}$, and Fiona K. A. Schmiegelow ${ }^{1}$ \\ ${ }^{1}$ Department of Renewable Resources, University of Alberta, Edmonton, Alberta, T9H 4N1 Canada \\ ${ }^{2}$ Fish and Wildlife Division, Alberta Sustainable Resource Development, Hinton, Alberta, T7V 2E6 Canada \\ ${ }^{3}$ Corresponding author: gkuzyk@ualberta.ca
}

Kuzyk, Gerald W., Jeff Kneteman, and Fiona K.A. Schmiegelow. 2004. Winter habitat use by Wolves, Canis lupus, in relation to forest harvesting in west-central Alberta. Canadian Field-Naturalist 118(3): 368-375.

Forested landscapes in west-central Alberta are facing increased pressures from forest harvesting and other land-use activities, which may alter the movements and distribution of Wolves and ungulates. Information on habitat use by Wolves in logged forests is scarce, potentially limiting effective land-use planning in the boreal forest. Nine Wolves, from four Wolf packs, were fitted with GPS radiocollars in the Rocky Mountain foothills, near Grande Cache, Alberta (2000-2001). We found Wolves did not use the landscape randomly, but rather exhibited a significant preference for non-forested natural habitats (shrubs, water), relative to their availability. Within forest habitats, Wolves used cutblocks proportionately more than unharvested forest and non-forested anthropogenic habitats (pipelines, clearings); however, selection of forest cutblocks was not statistically significant. We found no evidence that Wolves preferred or avoided forest cutblock edges. Wolf pack territories contained various levels of timber harvesting, but most areas were still in the early stages of harvest. Nevertheless, these areas have been allocated for large-scale harvesting. Understanding the potential responses of Wolves to rapidly changing landscape mosaics poses a significant challenge to researchers and managers, but such information is important to informing future land-management and conservation strategies for boreal forest Wolf-prey systems.

Key Words: Wolf, Canis lupus, Caribou, Rangifer tarandus, forestry, habitat, Moose, Alces alces, predation, Alberta.

Much of the world's boreal forest is undergoing increased demands from resource extraction industries, where related activities such as forest harvesting may alter habitat use by large carnivores (McLellan and Hovey 2001; White et al. 2001). Wolves (Canis lupus) are a common predator of ungulates in Canada's forests, yet there are few data on how their use of habitat might be affected by forest harvesting (Jedrzejewska et al. 1994; Kohira and Rexstad 1997; Kunkel and Pletscher 2000). Logging of forests can change the spatial dynamics of Wolves and their prey, resulting in conflict between resource development and wildlife management (Hervieux et al. 1996). For example, in Alberta, Woodland Caribou (Rangifer tarandus caribou) are classed as a threatened species (Edmonds 1998), and Wolf predation is considered a primary reason for their decline (Edmonds 1988; McLoughlin et al. 2003). It is therefore important to understand how Wolves respond to forest harvesting, as habitat use by Wolves may change in response to logging activities, and could affect predation risk to Caribou and other ungulates.

Forest harvesting can cause habitat fragmentation and alter predator-prey systems. Predators may follow habitat edges due to ease of travel (Bider 1968). As well, when patch size decreases, predator numbers may increase due to increased prey density and diversity (Gates and Gysel 1978; Yahner 1988). For example, Red Fox (Vulpes vulpes) and Coyote (Canis latrans) densities can increase with more landscape fragmentation, and habitat edges are favored for hunting (Oehler and Litvaitis 1996).
In a Wolf-prey system in Canada's boreal forest, forestry activities have the potential to alter the predation risk to ungulates from Wolves in three ways. First, differential spatial and temporal habitat selection separates Woodland Caribou and Moose (Alces alces) distribution, reducing the risk of predation to Caribou from Wolves (Bergerud and Elliot 1986). Caribou selection for higher elevations reduces the chance of encounter by Wolves hunting Moose, a primary prey species, in lower elevations riparian areas (Seip 1992). If the spatial separation of Caribou and Moose is altered by logging roads and forest cutblocks, it has been argued that Wolves will have increased access to, and greater encounter rates with Caribou, resulting in a Caribou decline (Bergerud 1988; Seip 1992). In northeast Alberta, linear developments (roads, seismic lines, trails) were found to affect the spatial separation between Caribou and Moose, where linear corridors enhanced Wolf travel efficiency (James 1999) and Caribou mortalities caused by Wolves were found closer to linear corridors than expected by chance (James and Stuart-Smith 2000).

Second, Caribou select for older forests (Szkorupa 2002) and distribute at low densities (Bergerud 1988). Caribou spatial overlap with Wolves is reduced and, correspondingly, so too is the risk of detection and predation. Reducing the amount and patch size of older forest by timber harvest may temporarily increase Caribou densities (Bergerud 1988), and Moose, deer (Odocoileus spp.) and Elk (Cervus elaphus) may use these remaining patches for cover. Higher densities of 
Caribou in more constricted areas, and wider distribution of Wolves in response to primary prey distribution, may increase the chances of Caribou being detected by Wolves.

Third, Moose, Elk and deer are attracted to recently logged areas that support high quality regenerating forage (Peek et al. 1976; Tomm et al. 1981; Stelfox et al. 2001). This represents a concentrated prey base for Wolves, which may influence how Wolves use landscapes. If Wolves frequent forest cutblocks searching for Moose, Elk and deer, and if cutblocks occur near preferred Caribou habitats, this may increase predation risk to Caribou. All three outcomes potentially affecting Caribou depend on information about Wolf behavior and use of changing landscapes.

Forest harvesting in west-central Alberta was largely initiated in the late 1960s and has accelerated in recent years. Energy sector activities (oil and gas exploration and development) are also altering these landscapes, resulting in cumulative land use impacts (Hervieux et al. 1996). For decisions concerning long term wildlife conservation, resource managers and land-use planners require new information about how Wolves use habitat in logged forests and under changing landscape conditions.
We used Global Positioning Systems (GPS) radiocollar technology to examine winter habitat use of Wolves in west-central Alberta. We chose to examine fine-scale Wolf movements that correspond with Johnson's (1980) third order habitat selection: movements of animals within their home range. We examined two questions. First, do Wolves use forest cutblocks preferentially over other habitat types? Second, do Wolves prefer cutblock edges? We predicted that Wolves would prefer forest cutblocks over other habitats, due to the expected increase in ungulate densities in regenerating forests. We also predicted Wolves would prefer forest cutblock edges relative to areas farther away from them, due to ungulate use of cutblock edges for feeding and proximity to cover (Stelfox et al. 2001*).

\section{Study Area}

The study area is approximately 5000 square kilometers, located in the foothills of west-central Alberta, near the town of Grande Cache $\left(54^{\circ} \mathrm{N} 119^{\prime} \mathrm{W}\right)$ (Figure 1). The area is classed into subalpine and boreal natural subregions (Beckingham and Archibald 1996), and contains several main rivers and a dendritic pattern of creeks; lakes are scarce. Elevations range from 1300-1800 meters, and the climate is subarctic, with

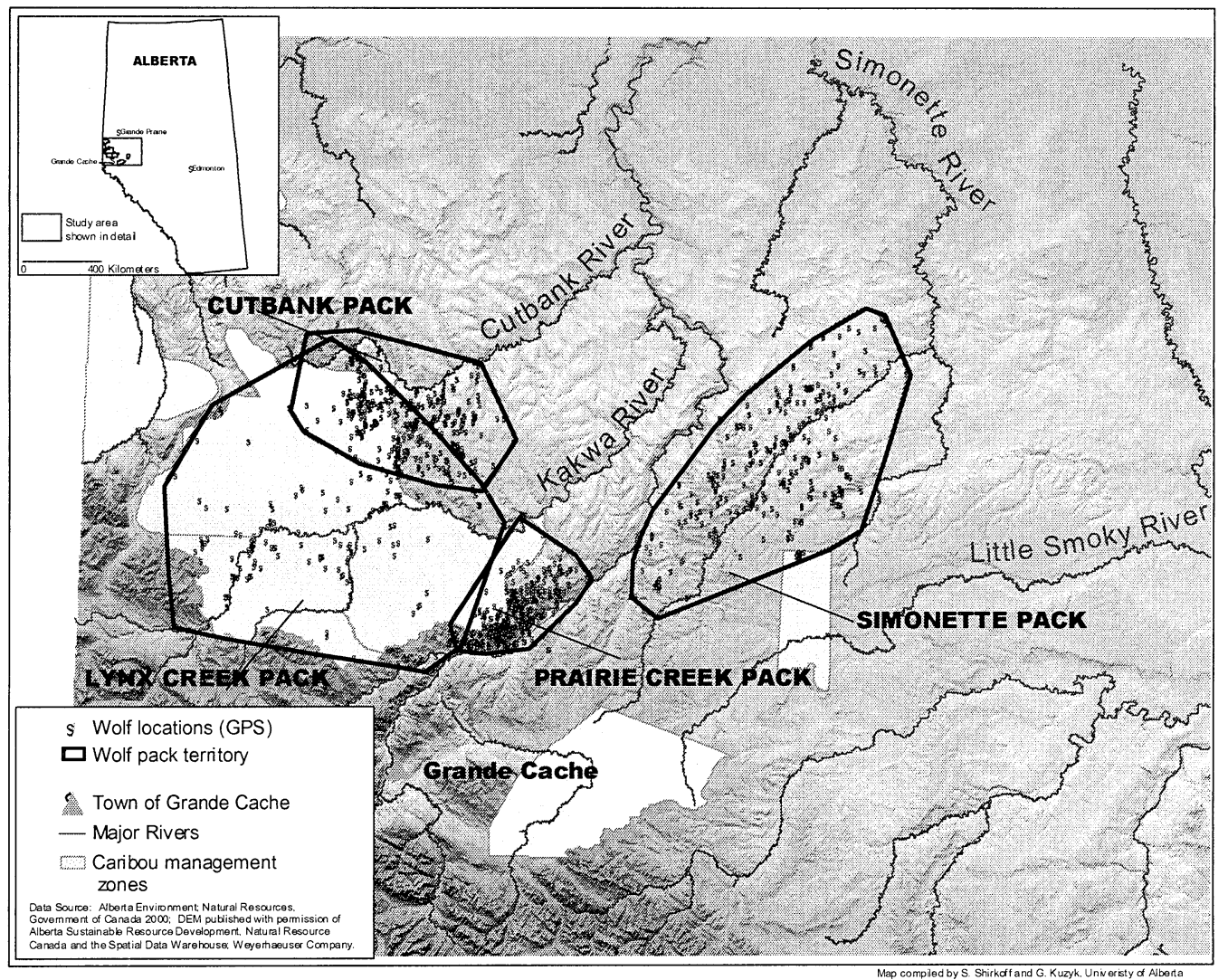

FIGURE 1. Distribution of four Wolf packs monitored in winters of 2000 and 2001 in west-central Alberta. 
short wet summers and long cold winters. Temperatures average $16^{\circ} \mathrm{C}$ in July and $-13.5^{\circ} \mathrm{C}$ in December (Beckingham and Archibald 1996). The forests are primarily Lodgepole Pine (Pinus contorta) and some White Spruce (Picea glauca). The wetland complexes support mostly Black Spruce (Picea mariana) and some Tamarack (Larix laricina). Some south facing slopes support Trembling Aspen (Populus tremuloides) and willow (Salix spp.).

This area supports a high diversity of large mammals: Woodland Caribou, Moose, Elk, Mule Deer (Odocoileus hemionus), White-tailed Deer (Odocoileus virginianus), Bighorn Sheep (Ovis canadensis), Mountain Goats (Oreamnos americanus) and Wild Horses (Equus cabalus). Wolves, Coyotes (Canis latrans), Grizzly Bears (Ursus arctos), Black Bears (Ursus americanus) and Cougars (Felis concolor) also exist throughout the study area.

Major land use activities include forest harvesting, oil and gas exploration and development, coal mining, commercial trapping, and public uses such as hunting, fishing, hiking, horse packing and camping. Access is primarily on roads created for resource extraction, pipelines and seismic lines. Further descriptions of the study area can be found in Edmonds (1988) and Smith et al. (2000).

\section{Wolf Location Data}

Nine Wolves in four packs were captured and fitted with GPS radiocollars in winters of 2000 and 2001 (Table 1). Three packs were located in areas with a migratory mountain Caribou population and one pack with a sedentary boreal Caribou population. All Wolf handling was approved by the Faculty of Agriculture, Forestry and Home Economics Animal Care Policy (Number 96-99D), subject to the protocols of the Canadian Council of Animal Welfare. Wolf captures were accomplished by helicopter darting (Ballard et al. 1991) or netgunning, then physically restraining the Wolf with restraining forks, and hand-injecting 1-2 mls of telazol at $200 \mathrm{mg} / \mathrm{ml}$ (Kuzyk 2002a). Wolves were fitted with store aboard GPS radiocollars (Lotek Engineering Sytems, Newmarket, Ontario). In the winter of 2001, the Prairie Creek and Cutbank packs each had two members with GPS radiocollars. To avoid pseudo- replication (Hurlburt 1984), location data and associated patterns of habitat use from these individuals were averaged for their respective packs (Table 1).

As this study was designed to understand Wolf habitat use in winter, the following criteria were used to select Wolf location data:

(1) Location data from 31 January to 25 April 25 in 2000 and 2001 were used for analyses. These dates were used for two reasons: first, most Caribou in the study area (the migratory mountain ecotype) leave the forested foothills in late winter and spring to calve in the nearby mountains (Edmonds 1988); second, a spring cutoff time also has ecological relevance to Wolves. In spring near whelping time, Wolves are thought to change their hunting patterns by switching from hunting as a pack and preying on ungulates, to hunting alone or in small units in search of smaller prey, with their activities centering on the den and pups (Mech 1970). Therefore a single GPS collared Wolf would no longer represent the behavior of their pack, and would not meet our design criteria.

(2) To provide consistency in GPS collar programming, six-hour locations were chosen (4 per day) as the minimum common sampling unit for analysis. Wolves are sporadic in their movements, and may travel at rates of about $8 \mathrm{~km} / \mathrm{hr}$ while hunting (Mech 1966), or relatively short distances when near a killsite (Kuzyk 2002a). When near a killsite, they seldom rest in one location for periods longer than six hours (Mech 1970).

(3) Wolf locations outside calculated pack territories were not used. These Wolves were assumed to be dispersing from their natal territory and thus behaving differently from their pack (Gese and Mech 1991).

Data were differentially corrected using N4Win Version 2.40 program (Lotek Engineering Inc. 2000) and were assumed accurate within 14 meters, $95 \%$ of the time (Lotek Engineering Inc. 2000). Wolf locations with Dilution of Precision (DOP) values greater than 15 were removed from the analysis $(<2 \%$ of total locations). High DOP values and radiocollar malfunctions made for unequal locations per Wolf pack (range 152 to 279) over the duration of this study (Table 1).

\section{Habitat Classification and GIS Methods}

Wolf location data were imported into ArcView Version 3.1 (Environmental Systems Research Institute Inc., Redlands, California). Current, digital forest inventory coverages were obtained from Weyerhauser Canada Limited, Canadian Forest Products and Al-

TABLE 1. Wolf packs with associated number of GPS locations and area of habitat use (territory size) in west-central Alberta in winters of 2000 and 2001.

\begin{tabular}{lllcrr}
\hline \hline Wolf Pack & Wolf & Year & Dates & Number of Locations & Area $\left(\mathrm{km}^{2}\right)$ \\
\hline Cutbank & W5 & 2000 & 24 January - 16 March & 185 & 714 \\
Prairie Creek & W9 & 2000 & 28 January - 25 April & 252 & 286 \\
Simonette & W13 & 2000 & 31 January - 25 April & 279 & 786 \\
*Prairie Creek & W5 and W9 & 2001 & 18 February - 25 April & 231 & 182 \\
* Cutbank & W19 and W21 & 2001 & 15 February - 25 April & 258 & 448 \\
Lynx Creek & W22 & 2001 & 15 February - 25 April & 247 & 1848 \\
Simonette & W30 & 2001 & 17 February - 4 April & 152 & 398 \\
\hline \hline
\end{tabular}

* Locations were averaged for two collared Wolves which belonged to the same pack. 
TABLE 2. Description of habitat categories used in compositional analysis for Wolf packs in west-central Alberta during late winters of 2000 and 2001.

\begin{tabular}{llll}
\hline \hline Habitat 1 & Habitat 2 & Habitat 3 & Habitat 4 \\
\hline $\begin{array}{l}\text { Forest cutblocks } \\
\text { all harvested forest }\end{array}$ & Unharvested forest & Non-forest (natural) & Non-forest (anthropogenic) \\
& all harvestable forest & clearing \\
burn & sand, flooded land & $\begin{array}{l}\text { right-of-way } \\
\text { industrial infrastructure } \\
\text { pipelines }\end{array}$ \\
& & closed and open shrub & geophysical \\
& coniferous scrub & perennial forest crops* \\
& deciduous scrub & \\
& brush, windfall & \\
& water and treed muskeg & \\
\hline \hline
\end{tabular}

*Perennial forest crops are denoted as anthropogenic by the forest companies and account for $<0.6 \mathrm{~km}^{2}$ of one Wolf pack's territory. (Simonette pack - total territory size is $786 \mathrm{~km}^{2}$ ).

TABLE 3. The percentage of use (GPS locations) and availability (area in $\mathrm{km}^{2}$ ) of five habitat categories for Wolf pack territories in west-central Alberta during late winters of 2000 and 2001.

\begin{tabular}{|c|c|c|c|c|c|c|c|c|c|c|c|}
\hline \multirow[b]{2}{*}{ Wolf Pack } & \multirow[b]{2}{*}{ Year } & \multicolumn{2}{|c|}{ Cutblock } & \multicolumn{2}{|c|}{ Forest } & \multicolumn{2}{|c|}{$\begin{array}{l}\text { Non-forest* } \\
\text { Shrubs }\end{array}$} & \multicolumn{2}{|c|}{$\begin{array}{l}\text { Non-forest* } \\
\text { Water }\end{array}$} & \multicolumn{2}{|c|}{$\begin{array}{c}\text { Non-forest } \\
\text { Anthropogenic }\end{array}$} \\
\hline & & Used_1 & Avail_1 & Used_2 & Avail_2 & Used_3 & Avail_3 & Used_4 & Avail_4 & Used_5 & Avail_5 \\
\hline Cutbank & 2000 & 34.1 & 28.9 & 57.8 & 64.6 & 7.0 & 5.4 & 1.1 & 0.3 & 0.0 & 0.8 \\
\hline Prairie Creek & 2000 & 11.9 & 12.5 & 77.8 & 80.2 & 6.7 & 4.8 & 1.2 & 1.0 & 2.4 & 1.5 \\
\hline Simonette & 2000 & 21.1 & 15.9 & 61.6 & 78.8 & 7.5 & 3.0 & 2.5 & 0.6 & 7.2 & 1.8 \\
\hline Prairie Creek & 2001 & 6.3 & 5.9 & 81.2 & 87.1 & 9.1 & 4.1 & 1.7 & 1.1 & 1.7 & 1.8 \\
\hline Cutbank & 2001 & 43.3 & 35.5 & 35.7 & 60.0 & 20.2 & 3.4 & 0.4 & 0.3 & 0.4 & 0.8 \\
\hline Lynx Creek & 2001 & 0.8 & 5.4 & 77.3 & 85.9 & 20.2 & 8.5 & 0.8 & 0.1 & 0.8 & 0.2 \\
\hline Simonette & 2001 & 16.4 & 14.0 & 68.4 & 78.3 & 13.2 & 5.5 & 0.7 & 0.5 & 1.3 & 1.7 \\
\hline \multirow[t]{2}{*}{ Total } & Mean & 19.1 & 16.9 & 65.7 & 76.4 & 12.0 & 5.0 & 1.2 & 0.6 & 2.0 & 1.2 \\
\hline & SE & 5.7 & 4.3 & 6.0 & 3.9 & 2.3 & 0.7 & 0.3 & 0.1 & 0.9 & 0.2 \\
\hline
\end{tabular}

*Non-forest natural is subdivided into shrub and water categories for descriptive purposes only.

berta Government Phase 3. The minimum mapping unit for these coverages was 1 ha for forest polygons. However, the resolution of line features, such as roads, was much greater, as these were spatially referenced from high-resolution remotely sensed data $(\sim 5 \mathrm{~m}$ resolution), or from GPS readings taken in the field. Thus, the resolution of our animal location data was commensurate with the resolution of the landscape coverages used, for purposes of evaluating coarse-scale habitat use. Minimum convex polygons (MCPs) of Wolf territories were initially calculated with an animal movement extension in ArcView (Hooge and Eichenlaub 1997). MCPs were considered an appropriate method for delineating general territory boundaries in order to evaluate coarse-scale habitat use. Due to a small portion of the GIS coverages missing within each Wolf pack territory, territory sizes for subsequent analyses were adjusted by summing all the areas within the MCPs for which we had GIS coverages (Table 1).

As Wolves live in a defined territory (Mech 1970), each territory was classified into four habitat categories to reflect coarse scale patterns of use. These categories were: (1) forest cutblocks, (2) unharvested forest, (3) non-forest natural (shrubs and water) and (4) non- forest anthropogenic (pipelines, wellsites) (Table 2). The area of non-forest natural was divided into "shrub" and "water" classes for descriptive purposes (Table 3 ), but the data were pooled for analysis. As the focus of this study was to determine habitat use of Wolves in managed landscapes, a further analysis was conducted to determine Wolf use of forest cutblock edges. Forest cutblocks were buffered using specified distances starting from the edge of the forest-cutblock and proceeding into the forest. We did not use locations inside cutblocks in this analysis. Buffer distances were consistent with those studying Caribou avoidance of linear features (Dyer et al. 2001; Oberg 2001), starting from the edge of the cutblock to $100 \mathrm{~m}, 101-250 \mathrm{~m}$, 251-500 m, 501-1000 $\mathrm{m}$ and $>1000 \mathrm{~m}$. The category of $>1000 \mathrm{~m}$ was also chosen as the farthest distance for comparison to Smith et al. (2000), who found that Caribou in west-central Alberta may avoid cutblocks by about $1200 \mathrm{~m}$.

\section{Statistical Analysis}

Compositional analysis (Aebischer et al. 1993) was conducted by integrating Wolf GPS location data and forest inventory data within a GIS (ArcView 3.1) to 
determine if there was a preference in Wolf use of habitat or buffer categories. Aebischer et al. (1993) suggest a minimum of six radiotagged animals are required to perform compositional analysis, and replication across years is acceptable. Therefore, our sample of seven Wolves over two winters was adequate for this test. Compositional analysis compares the amount of "used habitat" to the amount of "available habitat" and tests whether habitats are preferred or avoided more than expected by random (Johnson 1980). The number of Wolf locations in each habitat or buffer category represented used habitat. The available habitat was the total area of each habitat or buffer category (Table 3 ). If there was no use of a habitat category, $0 \%$ use was replaced with $0.001 \%$, as this represented a value lower than the smallest recorded nonzero percentage (Aebischer et al. 1993).

A chi-square test was used to determine if Wolf use of habitat or buffer categories was significantly nonrandom, then each habitat category was ranked in terms of its use. To determine if any habitats were selected over others, a difference for each pair-wise comparison was calculated using log ratios. This compared each habitat category within each Wolf pack territory. The means and standard errors for each comparison were calculated across all Wolf packs, and the pair-wise differences were tested for significance using a t-test (Aebischer et al. 1993). Alpha level for all tests was set at 0.05 .

\section{Results}

\section{Wolf Habitat Use}

Territory size for the four Wolf packs ranged from $182-1848 \mathrm{~km}^{2}$ (Table 1). The availability of each of the four habitat categories varied markedly: the percentage of forest averaged $76.40 \%$ (SE 3.90) for all packs, and thus was the most dominant habitat, whereas non-forest anthropogenic cover averaged only $1.23 \%$ (SE 0.25) of available habitat across Wolf territories (Table 3). Wolves showed a significant deviation from random use of the four habitat types $\left(\chi^{2}=7.815, \mathrm{df}=3\right.$, $\mathrm{p}=0.036$ ) selecting non-forest natural (shrubs-water) habitats over both forest $(\mathrm{t}=-4.281, \mathrm{df}=6, \mathrm{p}=0.005)$ and cutblocks $(\mathrm{t}=-2.92, \mathrm{df}=6, \mathrm{p}=0.027)$, in relation to their availability (Table 4). No other pair-wise comparisons were significant. However, when ranked in preference by habitat type, forest cutblocks were pref- erred more than both forest and non-forest anthropogenic areas.

\section{Wolf Response to Forest Cutblock Edges}

The available areas for all distance buffers less than $1000 \mathrm{~m}$ were similar, with variation due mostly to dissolving buffers for adjacent cutblocks. Wolf use of distance buffers did not deviate significantly from ran$\operatorname{dom}\left(\chi^{2}=2.349\right.$, df $\left.=3, p=0.503\right)$. When buffer distances were compared using compositional analysis, no significant difference was found between distance categories related to forest cutblock edges. When ranked, the 501-1000 m buffer distance was the most preferred, followed by the $0-100 \mathrm{~m}$ buffer, with the least preferred being the buffer $>1000 \mathrm{~m}$.

\section{Discussion}

Wolves have been described as habitat generalists (Mech 1970; Mladenoff et al. 1995). On a coarse spatial scale, Wolves inhabit large tracts of forest (Mech 1995) and may prefer mixed wood forests over either homogenous coniferous or deciduous forests (Mladenoff et al. 1995; Krizan 1997). Wolves may use forests altered by logging, as these areas provide good deer habitat, and thus support an important prey base for Wolves (Mladenoff and Sickley 1998). In this study, GPS radiocollar technology allowed for a more refined examination of Wolf habitat preferences, showing Wolves in our study area do not use the landscape randomly. In general, Wolves preferred habitats with young vegetation, in both non-forest natural habitats and forest cutblocks. This is consistent with increased ungulate abundance in areas of young vegetation (Peek et al. 1976; Stelfox et al. 2001*), which attract Wolves (Bergerud 1988). However, increased road access into these areas may also allow humans to alter activity patterns of Wolves (Theuerkauf et al. 2003), or affect Wolf numbers by direct or indirect killing (Mech 1995, Mladenoff and Sickley 1998). In this study, the least used habitat by Wolves was non-forest anthropogenic (pipelines, right-of-ways), possibly to avoid human contact. Two radio-collared Wolves were known to have been shot during this study, and several other collars were lost to unknown factors (Kuzyk 2002a).

We found little support for our first prediction that Wolves select forest cutblocks. Wolves did use cutblocks proportionately more than their availability and were ranked above forest or anthropogenic features,

TABLE 4. Results from compositional analysis ( $p$ values in parenthesis; + denotes row $>$ column and - column $>$ row) for comparing four habitat categories for four Wolf packs in west-central Alberta during late winters of 2000 and 2001.

\begin{tabular}{|c|c|c|c|c|c|}
\hline & & $\begin{array}{l}1 \\
\text { Cutblock }\end{array}$ & $\begin{array}{l}2 \\
\text { Forest }\end{array}$ & $\begin{array}{l}3 \\
\text { Non-for_natural }\end{array}$ & $\begin{array}{l}4 \\
\text { Non-for_anthropogenic }\end{array}$ \\
\hline 1 & Cutblock & & $+(0.947)$ & $-(0.027) *$ & $+(0.902)$ \\
\hline 2 & Forest & - & & $-(0.005) *$ & $+(0.903)$ \\
\hline 3 & Non-for_natural & + & + & & $+(0.177)$ \\
\hline 4 & Non-for_anthro. & - & - & - & \\
\hline
\end{tabular}

\footnotetext{
$*$ denotes significance at $(\mathrm{p}<0.05)$.
} 
but differences were not significant. Similarly, Wolves in Ontario were found to use cutblocks in proportion to their occurrence (Krizan 1997). We had the advantage of GPS radiocollars which allowed for a large collection of location data, compared with the traditional VHF collars used by Krizan (1997). However, we acknowledge that our analyses still lacked statistical power, due to the relatively small sample of Wolves radiocollared.

The amount of harvested forest differed substantially between Wolf packs and may have accounted for variation in Wolf use of forest cutblocks. The Lynx Creek pack had only $5 \%$ of its territory as forest cutblocks, whereas $36 \%$ of the Cutbank pack's territory consisted of recent cutblocks. This seven-fold difference in the amount of harvested forest between packs may have influenced habitat preferences. Kohira and Rexstad (1997) found no evidence that Wolf diets differed between logged and unlogged areas in the coastal rainforests of Alaska. About $6 \%$ of that total study area was logged, with the amount of area logged ranging from $1-26 \%$ between Wolf pack territories. This differs from our study area, where about $17 \%$, or approximately three times as much area has been logged. In southeast British Columbia, researchers also did not find evidence that forest harvesting increased the vulnerability of Moose to predation by Wolves, where about $13 \%$ of the area was logged (Kunkel and Pletscher 2000).

Wolves in our study did show a significant preference for non-forested natural habitats (shrubs/water) over cutblocks and forest, which might be explained by a number of selection criteria. Wolves prefer to rest in open areas, and may travel several kilometers to reach such preferred sites (Mech 1970). Wolves in this study area were observed on numerous occasions resting in open meadows, muskegs, hillsides and beaver ponds, often when they were near killsites (Kuzyk 2002a). The shrubs in these habitats have open crowns, which allows both penetration of sunlight and structure for protection from the wind, thus providing Wolves cover while resting.

The shrubs in this non-forest habitat type also provide forage and cover for ungulates. During this study, Wolves made deer kills in shrubby willow areas, and Moose, deer and Elk kills in or near riparian areas (Kuzyk 2002a). Elk are primarily grazers, and may be attracted to these shrub patches due to the increased availability of grasses. Bjorge and Gunson (1989), in a nearby Wolf study, noted that Elk, especially Elk calves, were a preferred prey for Wolves in winter. During the limited kill rate work associated with this study (Kuzyk 2002a), only one cow Elk kill was documented. In Jasper National Park, Wolves hunt deer while moving to pockets of Elk (Carbyn 1974; Weaver 1994). It is possible that shrubby areas do represent reliable patches of prey, and the Wolves investigate them for prey regularly.
Water was also included in this preferred habitat class. It is common for Wolves to use frozen waterways as travel routes where snow is most compacted and ice makes travel easy. In winter Wolves probably use creeks and rivers to travel among ungulate winter ranges. Also there is an increased chance of encountering Moose that use riparian areas in winter (Hayes et al. 2000) and Wolves are known to frequently kill ungulates on iced surfaces (Mech 1991).

Our second prediction of Wolf preference for forest cutblock edges was also not supported. There was no significant difference in Wolf preference for any buffer distance categories, nor was the 0-100 m buffer class ranked highest. Habitat was not controlled for in the buffer categories, which may have confounded the analysis. The behaviors of Wolves, such as feeding at killsites, resting and hunting may also be diluting the effect of any preference or avoidance of cutblock edges. Wolves hunt a diversity of prey, and chase distance varies with each prey type (Paquet 1989). For example, the average chase distance for a Moose is $883 \mathrm{~m}$ (Paquet 1989). Depending on where Wolves locate them, Moose could choose to run to the nearest forest to avoid attacking Wolves (Stephens and Peterson 1984), or remain stationary and aggressive (Mech 1966), or stationary and non-aggressive (Kuzyk 2002b), and still avoid attack by Wolves. These results, and those related to broader habitat selection questions, suggest that consideration of behaviors associated with different habitat types is an important component of interpretation in Wolf habitat use studies.

Forest harvesting alters both the amount and spatial distribution of habitat types. We measured habitat use by Wolves directly, and found that Wolf use of landscapes was not random. We suggest that patterns of habitat use may be influenced by the relative availability of different habitat types, specifically natural shrubs and waterways, and to a lesser degree, by recent forest cutblocks. Nevertheless, our results clearly show that consideration of shrub/waterway habitats is an important criterion for land-use decisions regarding Wolves. In our study area, Caribou prefer forests greater than 80 years old, especially those stands aged 120-160 years (Szkorupa 2002), and have been found to avoid forest cutblocks by $1200 \mathrm{~m}$ (Smith et al. 2000). As most of the winter range of these Caribou has been allocated for timber extraction, areas of older forest will become increasingly small and isolated. If the forest continues to be harvested at present rates, all Wolf packs we studied will have a substantial amount of logged area within their territories within a relatively short time. As Moose, deer and Elk are the primary prey of Wolves in this study area, information is required on how these ungulates are responding to the changing landscape mosaic, as this may ultimately determine how Wolves use the landscape. Understanding the dynamic relationship between predator and prey in a system undergoing rapid change 
poses an enormous challenge. Future research on Wolf habitat use should concentrate on increasing sample sizes, refining habitat classifications, and linking behavior with patterns of habitat use.

\section{Acknowledgments}

Funding for this research was provided by the WestCentral Alberta Caribou Standing Committee, the Alberta Sport, Recreation, Parks and Wildlife Foundation, and a University of Alberta Challenge Grant in Biodiversity (supported by the Alberta Conservation Association). A University of Alberta Graduate Research Assistantship and Margaret Brown Award in Environmental Studies and Wildlife Resources also provided financial assistance to G. Kuzyk. Additional financial support and digital forest inventory data were kindly provided by Weyerhaeuser Canada Ltd. and Canadian Forest Products. S. Shirkoff provided GIS support. We are thankful for the safe and expert piloting conducted by $\mathrm{C}$. Wilson from Bighorn Helicopters and D. Dennison from Coyote Air during wolf captures and monitoring. K. Smith and R. Hayes kindly reviewed the manuscript and added helpful suggestions.

\section{Documents Cited}

Stelfox, J. G., J. B. Stelfox, W. C. Bessie, and C. R. Clark. 2001. Longterm (1956-1996) effects of clearcut logging and scarification on forest structure and biota in spruce, mixedwood, and pine communities of west-central Alberta. Unpublished report.

\section{Literature Cited}

Aebischer, N. J., P. A Robertson, and R. E. Kenward. 1993. Compositional analysis of habitat use from animal radiotracking data. Ecology 77: 215-227.

Ballard, W. B., L. A. Ayres, K. E. Roney, and T. H. Spraker. 1991. Immobilization of gray wolves with a combination of tiletamine hydrochloride and zolazepam hydrochloride. Journal of Wildlife Management 55: 71-74.

Beckingham, J. D., and J. H. Archibald. 1996. Field guide to the ecosites of west-central Alberta. Canadian Forest Service, Nortwest Region, Northern Forestry Centre, Edmonton, Alberta.

Bergerud, A. T. 1988. Caribou, wolves and man. Trends in Ecology and Evolution 3: 68-72.

Bergerud, A. T., and J. Elliot. 1986. Dynamics of caribou and wolves in northern British Columbia. Canadian Journal of Zoology 64: 1515-1529.

Bider, J. R. 1968. Animal activity in uncontrolled terrestrial communities as determined by sand transect technique. Ecological Monographs 38: 269-308.

Bjorge, R. R., and J. R. Gunson. 1989. Wolf, Canis lupus, population characteristics and prey relationships near the Simonette River, Alberta. Canadian Field-Naturalist 103: 327-334.

Carbyn, L. N. 1974. Wolf predation and behavioral interactions with elk and other ungulates in an area of high prey diversity. Canadian Wildlife Service Report, Edmonton, Alberta.

Dyer, S. J., J. P O’Neil, S. M. Wasel, and S. Boutin. 2001. Avoidance of industrial development by woodland caribou. Journal of Wildlife Management 65: 531-542.
Edmonds, E. J. 1988. Population status, distribution and movements of woodland caribou in west central Alberta. Canadian Journal of Zoology 66: 817-826.

Edmonds, E. J. 1998. Status of woodland caribou in Alberta. Rangifer Special Issue 8: 111-115.

Gates, J. E., and L. W. Gysel. 1978. Avian nest dispersion and fledgling success in field-forest ecotones. Ecology 59: 871-883.

Hayes R. D., A. M. Baer, U. Wotschikowsky, and A. S. Harestad. 2000. Kill rate by wolves on moose in the Yukon. Canadian Journal of Zoology 78: 49-59.

Hervieux, D., J. Edmonds, R. Bonar, and J. McCammon. 1996. Successful and unsuccessful attempts to resolve caribou management and timber harvesting issues in west central Alberta. Rangifer Special Issue 9: 185-192.

Hooge, P. N., and B. Eichenlaub. 1997. Animal movement extension to Arcview. Version 1.1. Alaska Biological Science Center, United States Geological Survey, Anchorage, Alaska.

Hurlburt, S. H. 1984. Pseudoreplication and the design of ecological field experiments. Ecological Monographs 54: 187-211.

James, A. R. C. 1999. Effects of industrial development on the predator-prey relationship between wolves and caribou in northeastern Alberta. Ph.D. thesis, University of Alberta, Edmonton. 70 pages.

James, A. R. C., and A. K. Stuart-Smith. 2000. Distribution of caribou and wolves in relation to linear corridors. Journal of Wildlife Management 64: 154-159.

Jedrzejewska, B., H. Okarma, W. Jedrzejewski, and L. Milkowski. 1994. Effects of exploitation and protection on forest structure, ungulate density and wolf predation in Bialowieza Primeval Forest, Poland. Journal of Applied Ecology 31: 664-676.

Johnson, D. H. 1980. The comparison of usage and availability measurements for evaluating resource preference. Ecology 61: 65-71.

Kohira, M., and E. A. Rexstad. 1997. Diets of wolves, Canis lupus, in logged and unlogged forests of southeastern Alaska. Canadian Field-Naturalist 111: 429-435.

Krizan, P. 1997. The effects of human land development, landscape characteristics, and prey density on the spatial distribution of wolves (Canis lupus) on the north shore of Lake Superior. M.Sc. thesis, Acadia University, Wolfville, Nova Scotia. 108 pages.

Kunkel, K. E., and D. H. Pletscher. 2000. Habitat factors affecting the vulnerability of moose to predation by wolves in southeastern British Columbia. Canadian Journal of Zoology 78: 150-157.

Kuzyk, G. W. 2002a. Wolf distribution and movements on caribou ranges in west-central Alberta. M.Sc. thesis. University of Alberta, Edmonton, Alberta. 125 pages.

Kuzyk, G. W. 2002b. Female and calf moose remain stationary and non-aggressive when approached by wolves in west-central Alberta. Alberta Naturalist 31: 53-54.

McLellan, B. N., and F. W. Hovey. 2001. Habitats selected by grizzly bears in a multiple use landscape. Journal of Wildlife Management 65: 92-99.

McLoughlin, P., E. Dzus, B. Wynes, and S. Boutin. 2003. Declines in populations of woodland caribou. Journal of Wildlife Management 67: 755-761

Mech, L. D. 1966. The wolves of Isle Royale. U.S. National Park Fauna Series Number 7.

Mech, L. D. 1970. The wolf: ecology and behavior of an endangered species. Natural History Press, Doubleday Publishing Co., New York. 
Mech, L. D. 1991. The way of the wolf. Voyageur Press, Stillwater, Minnesota.

Mech, L. D. 1995. The challenge and opportunity of recovering wolf populations. Conservation Biology 9: 270-278.

Mladenoff, D. J., R. J. Haight, T. A. Sickley, and A. P. Wydeven. 1995. A regional landscape analysis and prediction of favorable gray wolf habitat in the northern Great Lakes region. Conservation Biology 9: 279-294.

Mladenoff, D. J., and T. A. Sickley. 1998. Assessing potential gray wolf restoration in the northeastern United States: a spatial prediction of favorable habitat and population levels. Journal of Wildlife Management 62: 1-10.

Oberg, P. R. 2001. Responses of mountain caribou to linear features in a west-central Alberta landscape. M.Sc. thesis, University of Alberta, Edmonton, Alberta. 126 pages.

Oehler, J. D., and J. A. Litvaitis. 1996. The role of spatial scale in understanding responses of medium-sized carnivores to forest fragmentation. Canadian Journal of Zoology 74: 2070-2079.

Paquet, P. C. 1989. Behavioral ecology of sympatric wolves (Canis lupis) and coyotes (C. latrans) in Riding Mountain National Park, Manitoba. Ph.D. thesis, University of Alberta, Edmonton, Alberta. 227 pages.

Peek, J. M., D. L. Urich, and R. J. Mackie. 1976. Moose habitat selection and relationships to forest management in northeastern Minnesota. Wildlife Monographs 48: 1- 65.

Seip, D. R. 1992. Factors limiting woodland caribou populations and their relationships with wolves and moose in southeastern British Columbia. Canadian Journal of Zoology 70: 1494-1503.
Smith, K. G., E. J. Ficht, D. Hobson, T. C. Sorensen, and D. Hervieux. 2000. Winter distribution of woodland caribou in relation to clear-cut logging in west-central Alberta. Canadian Journal of Zoology 78: 1433-1440.

Stephens, P. W., and R. O. Peterson. 1984. Wolf-avoidance strategies of moose. Holarctic Ecology 7: 239-244.

Szkorupa, T. D. 2002. Multi-scale habitat selection by mountain caribou in west-central Alberta. M.Sc. thesis, University of Alberta, Edmonton, Alberta. 92 pages.

Theuerkauf, J., W. Jedrzejewski, K. Schmidt, and R Gula. 2003. Spatiotemporal segregation of wolves from humans in the Bialowieza Forest (Poland). Journal of Wildlife Management 67: 706-716.

Tomm, H. O., J. A. Beck, and R. J. Hudson. 1981. Responses of wild ungulates to logging practices in Alberta, Canada. Canadian Journal of Forest Research 11: 606-614.

Weaver, J. L. 1994. Ecology of wolf predation amidst high ungulate diversity in Jasper National Park, Alberta. Ph.D. thesis, University of Montana, Missoula, Montana. 165 pages.

White, T. H., J. L. Bowman, H. A. Jacobson, B. D. Leopold, and W. P. Smith. 2001. Forest management and female black bear denning. Journal of Wildlife Management 65: 34-40.

Yahner, R. H. 1988. Changes in wildlife communities near edges. Conservation Biology 2: 333-339.

Received 4 April 2003

Accepted 23 November 2004 